\title{
SISTEM PENDUKUNG KEPUTUSAN TUMBUH KEMBANG SISWA TK MENGGUNAKAN METODE BEYOND CENTER And CIRCLE TIME (BCCT) DAN MATRIK SWOT IFAS DAN EFAS
}

\author{
Rayuwati $^{1}$, Ira Zulfa ${ }^{2}$, Husna Gemasih ${ }^{3}$, Rabumah $_{Z^{4}}$ \\ Universitas Gajah Putih \\ Takengon Aceh Tengah, Indonesia \\ rayuwati68@gmail.com
}

\begin{abstract}
Abstrak
Di dalam Pendidikan taman kanak-kanak (TK) seorang guru harus mampu mengarahkan anak didiknya dan memacunya untuk belajar mengenal berbagai pendekatan nilai diantaranya: agama, sosial, emosi, motorik, kognitif, bahasa, seni dan kemandirian untuk mengetahui tumbuh kembang anak usia 5-6 tahun, beberapa parameter yang dilakukan untuk pengujian 1) menentukan range nilai pariabel dari tingkat perkembangan anak berdasarkan tingkat urutan prioritas mulai dari belum berkembang (BB), mulai berkembang (MB), berkembang sesuai harapan(BSH), berkembang sangat baik (BSB), 2) penentuan skor dan nilai bobot dari pariabel penilaiian terhadap perkembangan anak, 3) perhitungan jumlah bobot dari Pembiasaan,kognitif,motorik,bahasa,emosi dan sosial anak, 4) melakukan swot dengan perhitungan IFAS dan EFAS. Dengan hasil total nilai tumbuh kembang anak 44,52, kekuatan $(21,19)$ dan peluang $(16,12)$ mendapatkan nilai yang lebih baik bila dibandingkan dengan kelemahan $(4,04)$ dan Ancaman 3,05) dalam menentukan nilai skor dengan. Sistem Pendukung keputusan akan mempermudah guru taman kanak-kanak (TK) dalam mengambil keputusan tentang tumbuh kembang anak dengan menggunakan metode Beyond Centers and Circle Time (BCCT) dengan perhitungan Matrik swot IFAS dan EFAS.
\end{abstract}

Kata Kunci : SPK, tumbuh kembang anak, BCCT,Matrik Swot IFAS dan EFAS 


\begin{abstract}
In kindergarten education (TK) a teacher must be able to direct their students and spur them to learn to recognize various value approaches including: religion, social, emotional, motor, cognitive, language, art and independence to determine the growth and development of children aged 5-6 years, several parameters carried out for testing 1) determine the range of pariable values from the level of child development based on the priority order level starting from underdeveloped $(B B)$, starting to develop $(M B)$, developing as expected $(B S H)$, developing very well (BSB), 2) determining the score and weight value of the assessment variables on children's development, 3) calculating the total weight of the child's habituation, cognitive, motoric, language, emotional and social, 4) performing SWOT with IFAS and EFAS calculations. With the results of the total value of children's growth and development of 44.52, strengths (21.19) and opportunities (16.12) get better scores when compared to weaknesses (4.04) and threats 3.05) in determining the score with the system. Decision support will make it easier for kindergarten (Tk) teachers to make decisions about children's growth and development using the Beyond Centers and Circle Time (BCCT) method by calculating the IFAS and EFAS Swot Matrices.
\end{abstract}

Keywords: SPK, child development, BCCT, IFAS and EFAS Swot Matrix 


\section{PENDAHULUAN}

Tempat yang aman dan nyaman untuk bermain bagi anak usia 4-6 tahun adalah di taman kanakkanak (TK), karna itu pendidikan di TK salah satu tempat tumbuh kembang anak dan guru harus memperhatikan tahap tumbuh kembang anak didik, baik dari pembiasaan, kognitif, motorik, bahasa, emosi dan sosial anak.

Bentuk penilaian yang dilakukan berbeda untuk tiap kriteria penilaian, untuk pembiasaan yang dinilai kemampuan berbaris dan berdo'a yang biasa dilakukan setiap hari, untuk kognitif yang dinilai kemampuan meniru tulisan, menghitung dan mengenal huruf, untuk motorik yang dinilai kemampuan memegang pensil, memegang sendok, menggunting dan melipat kertas, untuk emosi yang dinilai mengejek teman, marah dan merajuk, untuk sosial yang dinilai memilih teman dalam bergaul, berdiskusi dan saling berbagi.

Metode pembelajaran yang menyenangkan dapat membantu anak tumbuh dan berkembang dengan baik, di masa anak-anak merupakan masa yang tepat untuk mengasah karakter anak sehingga anak dapat tumbuh dan berkembang sesuai dengan kondisi anak itu sendiri. Untuk menentukan apakah anak yang sudah mampu tumbuh dan berkembang pasti mengalami kendala, dimana guru harus memberikan penilaian untuk setiap perkembangan yang terjadi pada setiap anak dengan mengisi lembar penilaian yang masih dilakukan secara manual, dengan banyaknya lembar penilaian tidak jarang guru mengalami kesalahan dalam pengisian data tumbuh kembang anak tersebut dan harus mengulangi pengisian data dengan data yang baru.

Dengan situasi yang demikian tidak jarang guru salah menginformasikan tumbuh kembang anak kepada orang tua siswa yang mungkin bertanya tentang perkembangan anak-anak mereka. Oleh karena itu, diperlukan sebuah cara yang bisa memudahkan pengambilan keputusan apakah anak tersebut telah berkembang dengan baik atau tidak.

Dalam metode Beyond Centers and Circle Time (BCCT) yang menjadi poin untuk tumbuh kembang siswa TK yaitu: pembiasaan, kognitif, motorik, bahasa, emosi dan sosial anak, metode ini sebagai cara untuk pengambilan keputusan dari perkembangan anak melalui penilaian yang dilakukan dari setiap anak yang telah mengalami perkembangan dengan persentasi yang telah benar. Hasil dari penilaian ini dimasukkan kedalam sistem kemudian sistem yang akan memproses dan memutuskan hasil penilaian tentang tumbuh kembang dari setiap anak.

Pertumbuhan adalah proses alamiah yang terjadi pada setiap individu, secara bertahap, berat dan tinggi anak semakin bertambah dan 
secara simultan mengalami peningkatan untuk berfungsi baik secara kognitif, psikososial maupun spiritual.

Perkembangan

adalah

perubahan secara berangsur-angsur dan bertambah sempurnanya fungsi alat tubuh, meningkatkan dan meluasnya kapasitas seseorang melalui pertumbuhan, kematangan/kedewasaan, dan pembelajaran. Perkembangan manusia berjalan secara progresif, sistematis dan berkesinambungan dengan perkembangan di waktu yang lalu. Perkembangan terjadi perubahan dalam bentuk dan fungsi kematangan organ mulai dari aspek fisik, intelektual, dan emosional.

Sistem Pendukung Keputusan (SPK) atau Decision Support System (DSS) adalah sebuah sistem yang mampu memberikan kemampuan pemecahan masalah maupun kemampuan pengkomunikasian untuk masalah dengan kondisi semi terstruktur dan tak terstruktur. Sistem ini digunakan untuk membantu pengambilan keputusan dalam situasi semi terstruktur dan situasi yang tidak terstruktur, dimana tak seorangpun tahu secara pasti bagaimana keputusan seharusnya dibuat

Beyond Centers and Circle Time (BCCT) atau dalam bahasa Indonesia dikenal dengan istilah pendekatan sentra dan lingkaran, yaitu suatu pendekatan penyelenggaraan pendidikan anak usia dini yang berfokus pada anak yang dalam proses pembelajarannya berpusat di sentra main dan saat anak dalam lingkaran dengan menggunakan 4 jenis pijakan (scaffolding) untuk mendukung perkembangan anak, yaitu pijakan lingkungan main, pijakan sebelum main, pijakan selama main dan pijakan setelah main.

Berdasarkan metode BCCT akan diperoleh data penilaian tumbuh kembang anak berdasarkan pengamatan dan dokumentasi kegiatan pembelajaran yang berupa daftar penilaian hasil pembelajaran.

Dengan menggunakan rumus sebagai berikut: $P=\frac{\mathrm{F}}{\mathrm{N}} \times 100 \%$

Langkah-langkah menyusun matriks faktor strategi internal (IFAS) dan matriks faktor strategi eksternal (EFAS) :

Menyusun kolom, 1 sampai dengan 10 Peluang dan Ancaman serta Kekuatan dan Kelemahan).

Masukkan skor (di dalam kolom 2) untuk masing masing faktor dengan memberikan skala mulai dari 1 sampai dengan 4 berdasarkan pengaruh faktor tersebut terhadap tumbuh kembang siswa yang bersangkutan. Pemberian nilai skor untuk faktor peluang bersifat positif (peluang yang semakin besar diberi skor 4 tetapi jika peluangnya kecil diberi skor 1), sedangkan pemberian skoruntuk ancaman adalah kebalikan dari pemberian skor peluang.

Beri bobot masing - masing faktor dalam kolom 3, mulai dari 0,09 (penting) sampai dengan 0,36 (sangat penting). 
Masukkan bobot pada kolom 4. Hasilnya berupa nilai pembobotan untuk masing - masing faktor yang nilainya bervariasi mulai dari 4,0 (outstanding) sampai 1,0 (poor).

Jumlahkan skor pembobotan (pada kolom 4), untuk memperoleh skor pembobotan bagi siswa yang bersangkutan. Nilai total ini akan menunjukkan bagaimana tumbuh kembang siswa bereaksi terhadap faktor - faktor strategis eksternalnya.

\section{METODE PENELITIAN}

Untuk membahas penelitian sistem pengambil keputusan terhadap tumbuh kembang anak menggunakan metode BCCT diperlukan tahapan penelitian seperti Gambar 1 dibawah ini

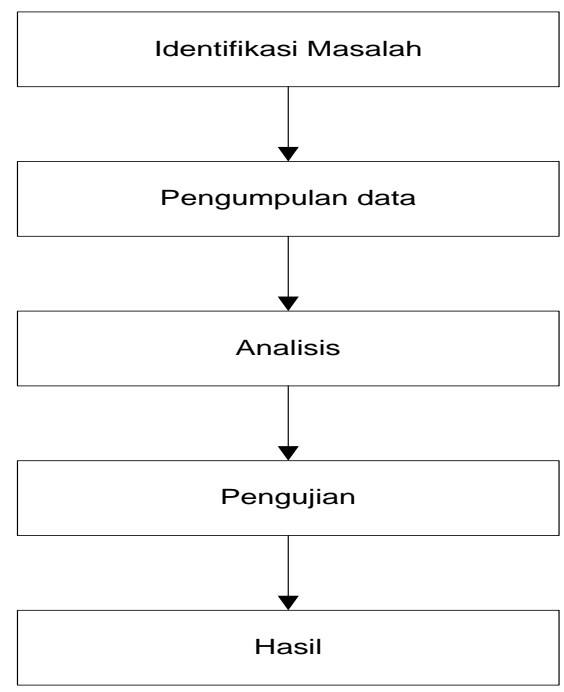

Gambar 1. Metodologi Penelitian

Penelitian ini dilakukan di TK.Budiara yang beralamat di Jln. Takengon-Wih Ilang Kampung Terang Ulen Kecamatan Pegasing Kabupaten Aceh Tengah. (sampel data).

Kegiatan pengumpulan data sekaligus, mengklasifikan dan pra analisis data, baik itu data internal maunpun eksternal,data internal dapat diperoleh dari dalam sekolah itu sendiri, antara lain: Laporan tumbuh kembang siswa, kegiatan belajar mengajar, Keadaan guru dan siswa, Fasilitas dan prasarana sekolah dan lain lain. Pada proses ini digunakan 2 model matriks pengumpulan data yaitu: matriks faktor strategi eksternal dan matriks faktor strategi internal dan data eksternal dapat diperoleh dari lingkungan di luar sekolah seperti: Peran orang tua, Teman dan Pemerintah.

\section{Analisis Sistem berjalan}

Analisis peneliti terhadap sistem yang sedang berjalan pada TK.Budiara khususnya dalam menentukan tumbuh kembang anak maka peneliti menemukan adanya kendala pada sistem pengambilan keputusan tumbuh kembang anak yang masih dilakukan secara manual.

Metode yang digunakan dalam identifikasi permasalahan yang terdapat pada Tk.Budiara adalah metode SWOT yang merupakan singkatan dari (Strength, Weakness, Opportunity dan Threats).

Analisa SWOT adalah suatu metode perencanaan strategis yang digunakan untuk mengevaluasi faktor-faktor yang menjadi kekuatan (Strength), Kelemahan (Weakness), Peluang (Opportunity), dan Ancaman (Threats) yang mungkin terjadi dalam mencapai suatu tujuan dari kegiatan 
lembaga dalam skala yang lebih luas. Untuk keperluan tersebut diperlukan kajian dari aspek lingkungan baik yang berasal dari lingkungan internal maupun eskternal yang mempengaruhi pola strategi institusi/lembaga dalam mencapai tujuan. Berdasarkan sudut pandang analisis yang menggunakan metode SWOT maka secara terperinci masalah yang dihadapi oleh Tk.Budiara khususnya dalam pengambilan keputusan tumbuh kembang siswa saat ini yaitu dapat dilihat pada Tabel 1 .

Tabel 1. Analisa SWOT

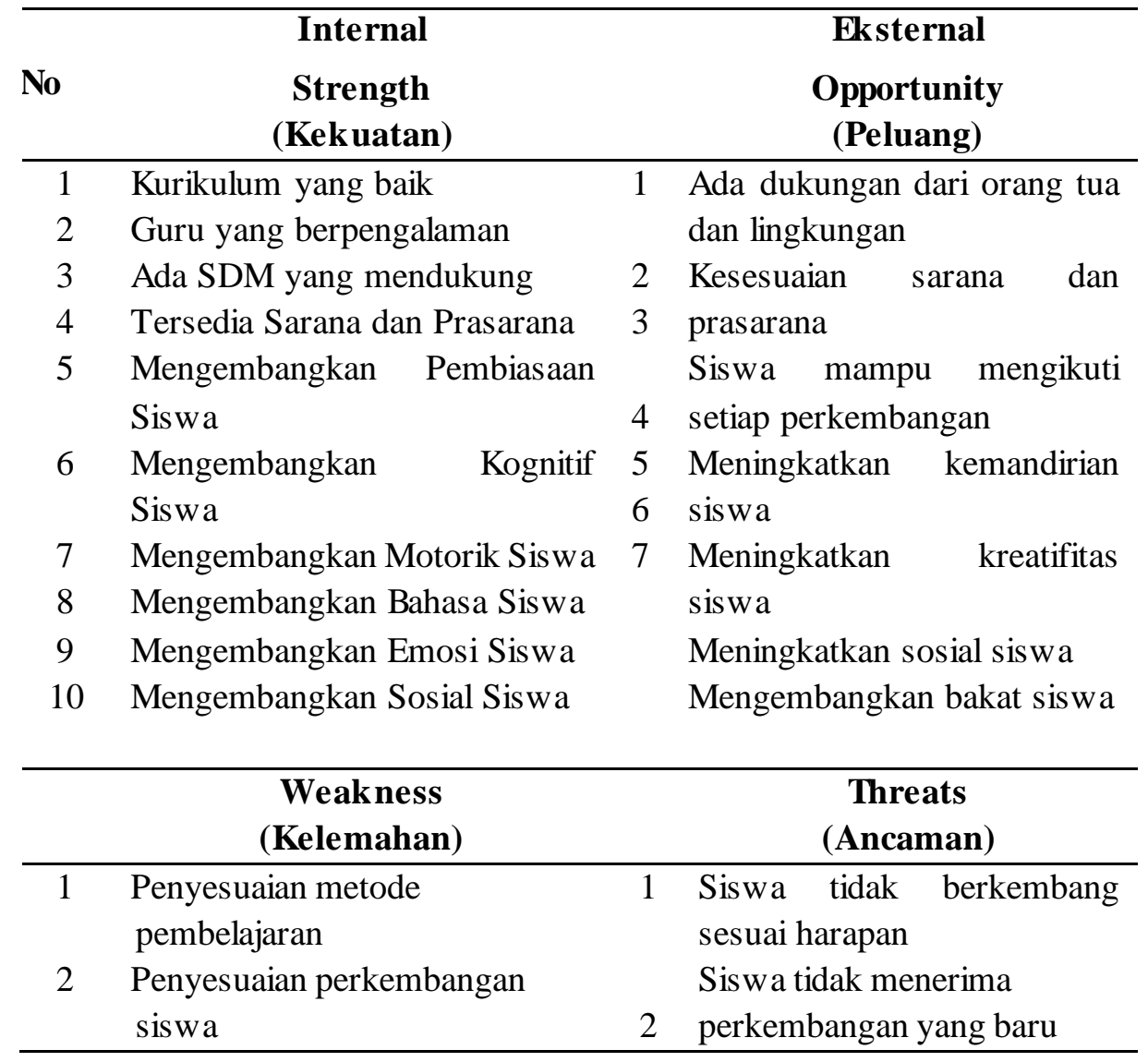

\section{Analisis SWOT yang diusulkan dengan matrik IFAS dan EFAS}

Setelah mendapatkan data dan informasi yang berkaitan dengan kelangsungan sekolah, maka selanjutnya memanfaatkan data dan informasi tersebut ke dalam model model kuantitatif perumusan strategi dengan matrik swot yang dapat dilihat pada Tabel 2 . 
Tabel 2. Matrik SWOT

STRENGTH
(Kekuatan) $\quad \begin{array}{r}\text { WEAKNESS } \\ \text { (Kelemahan) }\end{array}$

1. Kurikulum yang baik

2. Guru yang berpengalaman

3. Ada SDM yang mendukung

4. Tersedia Sarana dan Prasarana

SWOT 5. Mengembangkan Pembiasaan Siswa

6. Mengembangkan Kognitif Siswa

7. Mengembangkan Motorik Siswa

8. Mengembangkan Bahasa Siswa

9. Mengembangkan Emosi Siswa

10.Mengembangkan Sosial Siswa
1. Penyesuaian metode pembelajaran

2. Penyesuaian perkembangan siswa

\section{OPPORTUNITY}

(Peluang)

\begin{tabular}{|c|c|c|}
\hline $\begin{array}{l}\text { OPPORTUNITY } \\
\text { (Peluang) }\end{array}$ & S O & W 0 \\
\hline $\begin{array}{l}\text { 1. Ada dukungan dari } \\
\text { orang tua dan } \\
\text { lingkungan } \\
\text { 2. Kesesuaian sarana dan } \\
\text { prasarana } \\
\text { 3. Siswa mampu mengikuti } \\
\text { setiap perkembangan } \\
\text { 4. Meningkatkan } \\
\text { kemandirian siswa } \\
\text { 5. Meningkatkan } \\
\text { kreatifitas siswa } \\
\text { 6. Meningkatkan sosial } \\
\text { siswa } \\
\text { 7. Mengembangkan bakat } \\
\text { siswa }\end{array}$ & $\begin{array}{l}\text { 1. Menerapkan Kurikulum } \\
\text { yang ada disertai dengan } \\
\text { dukungan dari orang tua } \\
\text { dan lingkungan siswa } \\
\text { 2. Guru menyediakan sarana } \\
\text { dan prasarana untuk } \\
\text { mendukung perkembangan } \\
\text { SDM } \\
\text { 3. Mendidik siswa untuk } \\
\text { mengembangkan } \\
\text { pembiasaan, kognitif, } \\
\text { motorik, bahasa, emosi dan } \\
\text { sosial }\end{array}$ & $\begin{array}{l}\text { 1. Dukungan dari } \\
\text { orang tuaa dan } \\
\text { lingkungan } \\
\text { mempengaruhi } \\
\text { cara pembelajaran } \\
\text { 2. Sarana dan } \\
\text { prasarana sangat } \\
\text { mempengaruhi } \\
\text { perkembangan } \\
\text { siswa }\end{array}$ \\
\hline $\begin{array}{l}\text { THREATS } \\
\text { (Ancaman) }\end{array}$ & $\mathbf{S ~ T}$ & $\mathbf{W} \mathbf{T}$ \\
\hline $\begin{array}{l}\text { 1. Siswa tidak berkembang } \\
\text { sesuai harapan } \\
\text { 2. Siswa tidak menerima } \\
\text { perkembangan yang } \\
\text { baru }\end{array}$ & $\begin{array}{l}\text { Menyesuaikan kurikulum } \\
\text { dengan perkembangan yang } \\
\text { telah dicapai siswa }\end{array}$ & $\begin{array}{l}\text { Memperhatikan } \\
\text { metode pembelajaran } \\
\text { yang sesuai dengan } \\
\text { perkembangan siswa }\end{array}$ \\
\hline
\end{tabular}




\section{Sebelum}

melakukan

perhitungan terlebih dahulu harus menentukan range nilai skor berdasarkan tingkat perkembangan yaitu

$1=$ belum berkembang $(\mathrm{BB})$

$2=$ Mulai berkembang $(\mathrm{MB})$

$3=$ Berkembang sesuai harapan

(BSH)

4= Berkembang sangat baik (BSB)

Untuk mengetahui jumlah nilai dari setiap range dimasukan dengan menggunakan metode Beyond Centers And Circle Time (BCCT)

Berdasarkan metode BCCT akan diperoleh data penilaian tumbuh kembang anak berdasarkan pengamatan dan dokumentasi kegiatan pembelajaran yang berupa daftar penilaian hasil pembelajaran. Dengan rumus sebagai berikut :

$\mathrm{P}=\frac{\mathrm{F}}{\mathrm{N}} \times 100 \%$

$\mathrm{P}=$ Persentase yang diperlukan

$\mathrm{F}=$ Frekuensi nilai siswa

$\mathrm{N}=$ Jumlah siswa

$100=$ Persentase

\section{HASIL DAN PEMBAHASAN}

Perolehan hasil dari penelitian ini berupa keluaran keputusan tentang tumbuh kembang anak siswa TK. Hasil pengolahan dengan menggunakan metode BCCT dan perhitungan swot dengan IFAS dan EFAS seperti pada tabel dibaw ah ini
Tabel 3. Hasil Tumbuh Kembang

Siswa

\begin{tabular}{|c|c|c|c|c|c|}
\hline \multirow[t]{2}{*}{ No } & Total & \multicolumn{4}{|c|}{ Matrik Swot IFAS dan EFAS } \\
\hline & $\begin{array}{c}\text { Tumbuh } \\
\text { Kembang } \\
\text { Anak }\end{array}$ & Strength & Weakness & Opportunities & Threats \\
\hline 1 & $\overline{44,52}$ & 21,19 & $\overline{4,04}$ & 16,12 & 3,05 \\
\hline
\end{tabular}

\section{Parameter}

Adapun parameter yang diujikan pada penelitian ini antara lain

pembiasaan,kognitif,motorik, bahasa,e mosi dan sosial anak.

1. Menentukan Range nilai variabel dari tingkat perkembangan anak berdasarkan tingkat urutan prioritas.

2. Penentuan skor dan nilai bobot dari pariabel penilaiian terhadap perkembangan anak

3. Perhitungan jumlah bobot dari Pembiasaan,kognitif,motorik, bah asa,emosi dan sosial anak

4. Melakukan swot dengan perhitungan IFAS dan EFAS untuk mengetahui nilai kekuatan,kelemahan,peluang dan ancaman dari dari hasil keputusan tersebut.

\section{Proses Hasil Keputusan Tumbuh} kembang Anak Dengan Keluaran Manual

Proses keluaran terhadap hasil keputusan melalui tahapan sebagai berikut :

1. Menentukan Range nilai variabel dari tingkat perkembangan anak berdasarkan tingkat urutan prioritas, yaitu : 
$1=$ Belum berkembang $(\mathrm{BB})$

$2=$ Mulai berkembang $(\mathrm{MB})$

$3=$ Berkembang Sesuai harapan

$\mathrm{BSH})$

4 = Berkembang sangat baik

(BSB)

2. Penentuan skor dan nilai bobot dari variabel penilaian terhadap perkembangan anak yaitu :

a. Menentukan range variabel penilaian

$1=$ Bahasa dan emosi

$2=$ Kognitif dan Motorik

$3=$ Pembiasaan

$4=$ Sosial

b. Menentukan bobot skor terhadap masing masing variabel penilaian

Maka :

$$
\begin{aligned}
& P=\frac{1}{11} \times 100 \%=0,09 \\
& P=\frac{2}{11} \times 100 \%=0,18 \\
& P=\frac{3}{11} \times 100 \%=0,27 \\
& P=\frac{4}{11} \times 100 \%=0,36
\end{aligned}
$$

3. Menentukan Bobot terhadap variabel penilaian dari tumbuh kembang anak digunakan rumus : (Nilai Skor x jumlah siswa) + persentasi skor $(0,09$ X $11+$ $0,04)$

Keterangan :

1. Nilai Skor diperoleh dari perhitungan yang pertama,
2. $11=$ Jumlah siswa

3. $0,04=$ Hasil pembagian skor dengan persentase $\left(\frac{4}{100}\right)$, dengan hasil pembagian ini diperoleh bobot tertinggi dan terendah yaitu 1,0 sampai dengan 4,0 .

Cara menghitung :

$$
\begin{aligned}
& (0,09 \times 11+0,04)=1,03 \\
& (0,18 \times 11+0,04)=2,02 \\
& (0,27 \times 11+0,04)=3,01 \\
& (0,09 \times 11+0,04)=4,0
\end{aligned}
$$

\begin{tabular}{|c|c|c|c|c|c|}
\hline Penilaian & Nilai & $\begin{array}{l}\text { Nilai } \\
\text { bobot }\end{array}$ & Jumlah & $\begin{array}{l}\text { Total } \\
\text { Nilai }\end{array}$ & Hasil \\
\hline Pembiasaan & 3 & 0,27 & 3,01 & \multirow{6}{*}{$\begin{array}{l}\text { Cara } \\
\text { menghitung: } \\
11,13 \times 4= \\
44,52 \\
\text { Jadi Total } \\
\text { Nilai = } \\
44,52\end{array}$} & \multirow{6}{*}{$\begin{array}{c}\text { BB } \\
\text { (Belum } \\
\text { Berkem } \\
\text { bang) }\end{array}$} \\
\hline Kognitif & 2 & 0,18 & 2,02 & & \\
\hline Motorik & 2 & 0,18 & 2,02 & & \\
\hline Bahasa & 1 & 0.09 & 1,03 & & \\
\hline Emosi & 1 & 0,09 & 1,03 & & \\
\hline Sosial & 2 & 0,18 & 2,02 & & \\
\hline Jumlah Bol & & \multicolumn{4}{|c|}{11,13} \\
\hline
\end{tabular}

Untuk Mendapatkan Total Nilai digunakan rumus : (Jumlah Bobot x Jumlah Skor)

Tabel 4. Total Nilai Bobot

Dari uraian diatas dapat disimpulkan bahwa total nilai 44,52 dari $100 \%$ hanya mencapai hasil $\mathrm{BB}$ (Belum Berkembang).

4. Melakukan swot dengan
Perhitungan IFAS EFAS 
Tabel 5. Perhitungan IFAS

\begin{tabular}{lccc}
\hline Faktor - Faktor strategi Internal & Skor & $\begin{array}{c}\text { Nilai Skor } \\
\left(\mathbf{P}=\frac{\mathbf{F}}{\mathbf{N}} \mathbf{x} \mathbf{1 0 0} \%\right)\end{array}$ & $\begin{array}{c}\text { Bobot } \\
\text { (nilai skor x11) + 0,04 }\end{array}$ \\
\hline Kurikulum yang baik & 3 & 0,27 & 3,01 \\
\hline Guru yang berpengalaman & 3 & 0,27 & 3,01 \\
\hline Ada SDM yang mendukung & 2 & 0,18 & 2,02 \\
\hline Tersedia Sarana dan Prasarana & 3 & 0,27 & 3,01 \\
\hline Mengembangkan Pembiasaan Siswa & 2 & 0,18 & 2,02 \\
\hline Mengembangkan Kognitif Siswa & 2 & 0,18 & 2,02 \\
\hline Mengembangkan Motorik Siswa & 2 & 0,18 & 2,02 \\
\hline Mengembangkan Bahasa Siswa & 1 & 0,09 & 1,03 \\
\hline Mengembangkan Emosi Siswa & 2 & 0,18 & 2,02 \\
\hline Mengembangkan Sosial Siswa & 1 & 0,09 & 21,19 \\
\hline Jumlah & & & \\
\hline
\end{tabular}

\begin{tabular}{llcc}
\hline WEAKNESS (Kelemahan) & & & \\
\hline Penyesuaian metode pembelajaran & 2 & 0,18 & 2,02 \\
\hline Penyesuaian perkembangan siswa & 2 & 0,18 & 2,02 \\
\hline Jumlah & & & 4,04 \\
\hline Total S-W & & 17,15 \\
\hline
\end{tabular}

Rumus $X=S-W=21,19-4,04=17,15$

Tabel 6. Perhitungan EFAS

\begin{tabular}{lccc}
\hline \multicolumn{1}{c}{$\begin{array}{c}\text { Faktor }- \text { Faktor strategi } \\
\text { Eksternal }\end{array}$} & Skor & $\begin{array}{c}\text { Nilai Skor } \\
\left(\mathbf{P}=\frac{\mathbf{F}}{\mathbf{N}} \mathbf{x} \mathbf{1 0 0} \%\right)\end{array}$ & $\begin{array}{c}\text { Bobot } \\
\text { OPPO RTUNITY (Peluang) }\end{array}$ \\
\hline $\begin{array}{l}\text { Ada dukungan dari orang tua dan } \\
\text { lingkungan }\end{array}$ & 3 & 0,27 \\
\hline $\begin{array}{l}\text { Kesesuaian sarana dan prasarana } \\
\text { Siswa mampumengikuti setiap } \\
\text { perkembangan }\end{array}$ & 2 & 0,18 & 3,01 \\
\hline Meningkatkan kemandirian siswa & 2 & 0,27 & 2,02 \\
\hline
\end{tabular}




\begin{tabular}{lccc}
\hline Meningkatkan kreatifitas siswa & 2 & 0,18 & 2,02 \\
\hline Meningkatkan sosial siswa & 2 & 0,18 & 2,02 \\
\hline Mengembangkan bakat siswa & 2 & 0,18 & 2,02 \\
\hline Jumlah & & & 16,12 \\
\hline
\end{tabular}

\section{THREATS (Ancaman)}

\begin{tabular}{lccc}
\hline Siswa tidak berkembang sesuai harapan & 2 & 0,18 & 2,02 \\
\hline Siswa tidak menerima perkembangan yang baru & 1 & 0,09 & 1,03 \\
\hline Jumlah & & 3,05 \\
\hline Total O-T & & 13,07 \\
\hline
\end{tabular}

Rumus $\mathrm{Y}: \mathrm{O}-\mathrm{T}=16,12-3,05=13,07$

Berdasarkan nilai SWOT pada Tabel 5 dan Tabel 6, terdapat kesimpulan nilai sebagai berikut :

1. Kekuatan $($ Strength $)=21,19$

2. Kelemahan (Weakness) $=4,04$

3. Peluang (Opportunities $)=16,12$

4. Ancaman (Threats) $=3,05$

\section{Q0 Halaman Untuk Masuk}

SILAHKAN ISI NAMA DAN KATA SANDI ANDA

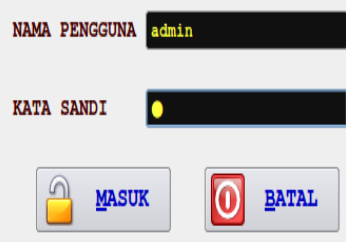

Gambar 2. Form admin

Form admin pada Gambar 2 adalah tampilan pada saat masuk ke dalam sistem dengan menggunakan nama pengguna dan kata sandi yang sudah di registrasi di sistem.

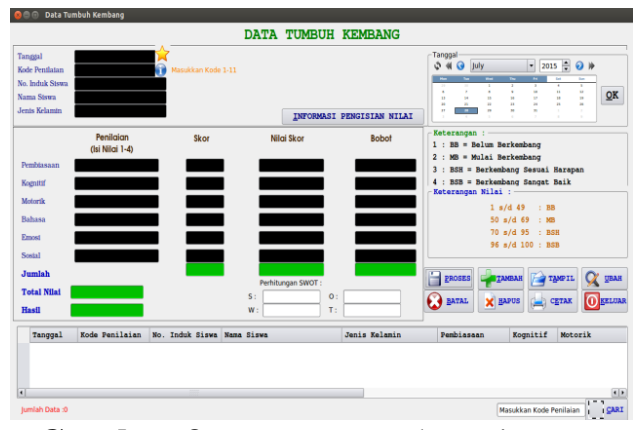

Gambar 3.Form Input data siswa

Form isian input data siswa pada Gambar 3 adalah tampilan pada sistem form menu untuk mengisi data siswa.

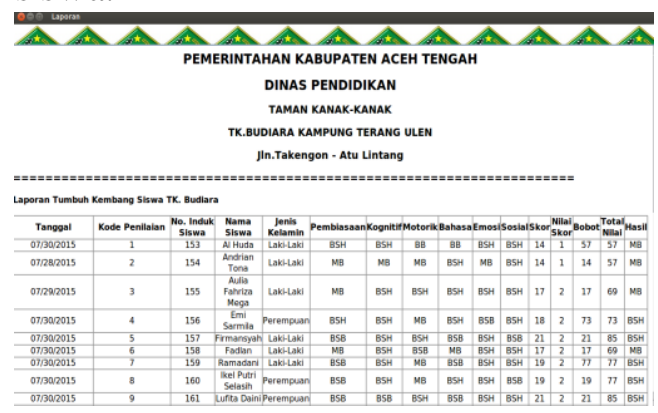

Gambar 4 Tampilan data siswa 
Gambar 4 menunjukkan tampilan data siswa yang telah diisi melalui

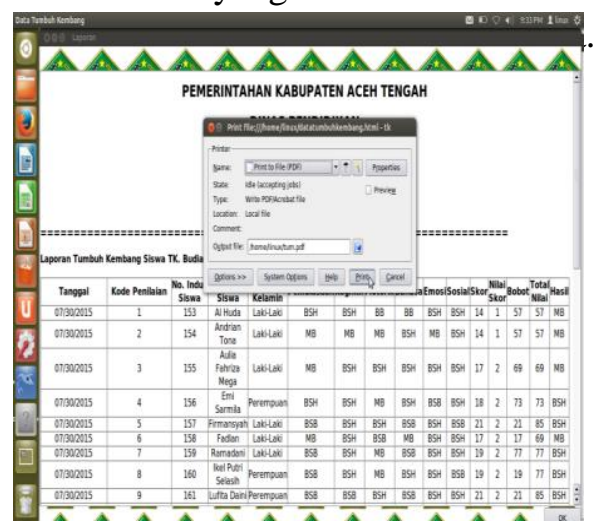

Gambar 5. Form Output Data siswa

Form Output data siswa pada Gambar 5 adalah tampilan pada sistem keluaran data siswa.

\section{KESIMPULAN DAN SARAN}

Melalui Sistem Pendukung Keputusan ini para guru mudah dalam pengambilan keputusan terhadap tumbuh kembang Siswa TK Budiara dan, hasil analisa menggunakan SWOT dalam penelitian ini menunjukan kekuatan $(21,19)$ dan peluang $(16,12)$ mendapatkan nilai yang lebih baik bila dibandingan dengan kelemahan $(4,04)$ dan Ancaman 3,05) penilaian terhadap tumbuh kembang siswa TK Budiara.

Saran untuk penelitian ini yaitu:

1. Diharapkan dapat melakukan penelitian kembali dengan Analisis data menggunakan matrik SPSCE, Matrik Grand Strategy atau Matrik BCG sebagai bahan perbandingan.
2. Untuk pembaca yang ingin mengembangkan penelitian ini diharapkan dapat membuat aplikasi untuk tingkat SD umur 712 tahun.

\section{DAFTAR PUSTAKA}

Dalyono, M. 2010, Psikologi Pendidikan, Yogyakarta, Rineka Cipta

Fatmawati dkk. 2019. Implementasi model pembelajaran sentra di TK Amal Insani,Jurnal Ilmiah Tumbuh Kembang Anak Usia Dini, Vol 4, No 2

Hartini,dkk, 2013. Peningkatan kemandirian Melalui Metode Demonstrasi Anak 5-6 Tahun.Pontianak:Universitas Tanjungpura

Kusrini. 2007. Konsep dan Aplikasi Sistem Pendukung keputusan, Jogyakarta,Andi, Offset

Mubiar, Ahmad. 2013. Dinamika Perkembangan Anak dan Remaja, Bandung, Refika Aditama.

Nur Hamzah. 2016. Pelaksanaan Pembelajaran BCCT bagi anak usia dini,Jurnal Agama Islam, Vo 10,No 2, hal 119-132

Very Isw antiningtyas,dkk. 2019. Penanaman Pendidikan karakter pada model 
pembelajaran BCCT,Junal

Obsesi, Vol3 issue 1, Hal 110-

116

Ramly.2009.Jurnal Pendidikan dan

Kebudayaan.Jakarta:Badan

Penelitian dan Kebudayaan

Departemen Pendidikan

Nasional.

Simarta, Janner, 2010, Basis Data, Yogyakarta,Andi.

Yuniar,dkk.2013.Penerapan Model Pembelajaran Beyond Centers and CircleTime (BCCT) Meningkatkan Minat dan Aktivitas Belajar Anak Kelompok B TK Bumi Gora $B P K B M$

NTB.Singaraja:Universitas

Pendidikan Ganesha 